\title{
EDUGATION IN NUTRITION IN THE UNITED KINGDOM
}

\author{
Chairman : Professor JOHN YUDKIN, Department of Physiology, \\ Queen Elizabeth College, University of London
}

\section{The Education of the Schoolchild in Nutrition}

\author{
By Evelyn M. Hale, H.M. Inspector of Schools, Ministry of Education, \\ Curzon Street, London, W. I
}

\section{Introduction}

The nutritional education of the schoolchild is designed to provide him with an understanding of what constitutes a state of good nutrition, the desirability of such a state and his responsibilities in the matter. The subject is first studied in relation to himself as of direct interest to the child. A consideration of the needs of the community may develop later.

The school life of the average child extends from 5 to 15 , or perhaps 18 , years with a possible Nursery School period from 3 to 5 . It is organized as follows :

$$
\begin{aligned}
& \text { Nursery School, not universal, 3-5 years } \\
& \text { Infant School } \quad 5-7 \text { years } \\
& \text { Primary School } \quad 7^{-1} \text { I years } \\
& \text { Thereafter Secondary Modern II-I } 5 \text { years } \\
& \text { or } \\
& \text { Secondary Technical II-I6 years } \\
& \text { or } \\
& \text { Grammar or equal II-I } 8 \text { or } 19 \text { years. }
\end{aligned}
$$

In presenting this subject, it is essential to bear in mind

the pupils' immediate needs, their powers of comprehension and interests, the extent to which they can control matters and the future for which they are preparing.

\section{Procedure}

Little if any direct teaching in the subject can be given in the Nursery and Infant School, but the routine can be so organized that valuable habits are formed through the children's daily activities, and their interest may be enlisted by judicious selection of topics for consideration and discussion. At this stage the routine is all-important, especially as the time spent in school is short and not all home influence is enlightened or systematic, so that the school is limited to what it can do in the allotted 5 hours a day. 


\section{Primary education}

In the Primary School teaching leads on from the Infants' stage in somewhat the same way. However the increasing tempo of general education gives less time for consideration of a desirable way of life, and a serious effort has to be made if good habits are to be retained. It is still possible, though less easy, to cash in on the more formal teaching, but this is important, since nutrition as such is not usually taught as a subject and there is danger of losing the ground already gained. The use of pictures or posters of the simplest kind is advocated. These should present one simple fact related to the child's interest and experience, such as care of teeth, milk makes you grow, clean food habits.

Thus nutrition, though not taught as a subject, may well find a place in many of the current centres of interest, the emphasis being still on the attitude of mind, namely, a sense of personal responsibility, together with a few useful facts to be absorbed while the child's mind is at a particularly retentive stage. There is no attempt to provide scientific explanation. A useful link may be forged with the work in physical education carried out elsewhere in the school.

Up to the end of the Primary School, that is, to the age of I r plus, all children go approximately the same way. By then they should have acquired a certain sense of responsibility for themselves and a respect and desire for positive health. They should have developed a liking for a variety of simple wholesome foods and should have learned to expect properly balanced meals and a certain way of life. In this, the school meal can play an important part by providing well-cooked, decently served and varied food, eaten under civilized conditions, which should include avoidance of waste and the introduction of new nourishing dishes. Here again, if the home influence is enlightened the work is made easier, but often there is little or no support there, and the school is limited by the relatively short time available. In any event there will probably have been no formal teaching of the subject.

After the Primary stage the situation changes, in that one of at least seven different paths may be followed and the curriculum may differ for boys and girls. Both the Modern School and the Grammar School may contain at least three different streams pursuing different objectives. The Secondary Technical Schools are hardly yet established and will not be considered.

\section{Modern Secondary Schools}

The approach to nutrition varies. Modern schoolgirls meet it in housecraft and to varying extents in science. Boys must usually depend on biology, nature study and gardening. Only very few learn cookery. A certain amount can be done for them by the general tone and habit of the school life, and particularly by the school meal, if it is a good one, but this must be weighed against unpredictable and often unenlightened home conditions.

Formal teaching has to be governed by the aptitude and ability of both teacher and class and by the facilities available. The Modern School caters for the less academically able pupils of a wide range of intelligence; the weakest streams may 
never get much further than primary level. The aim is to provide for them a very little essential knowledge, in the most helpful way for a girl who will probably be obliged, sooner or later, to assume responsibility for a family, but whose mental powers are limited. The approach is essentially practical and related to her daily experience. She is unlikely to study much science and will be baffled by unusual terminology. She is taught to prepare simple attractive dishes that capture her interest, and their food value is explained in terms of three groups with homely names. In time it is hoped that she will be able to plan and prepare very simple but adequate family meals that should serve sufficiently well for safety and will have grasped that this matters. She should also be aware of the rudiments of kitchen hygiene. The course may last from $I$ to 3 years, an average being 2 years of halfday classes.

The pupils in the ablest stream will be those who just missed the Grammar School and who possess good intelligence. They are likely to be doing science, including useful biology. Modern Schools often contain a good laboratory or two and the biology may be taught by a science graduate. With good co-operation, and a housecraft course of reasonable duration conducted in good premises, valuable work is then possible. The course may begin with a simple introduction to the food groups, probably three for a start, with homely names, since this should be the basis of all cookery. How far the Modern School girl can or should go with more scientific nomenclature depends on circumstances already enumerated and on the science taught in the school, but the aim is always to assist the potential housewife to meet her responsibilities as intelligently as possible, and to interest her in a matter of great importance, without confusing her with excessive scientific detail. It is hoped that she will be able to cater efficiently for a family within a reasonable budget by the age of 15 and, though her repertoire be limited, provide attractive menus, and that she will have a fair background of useful working knowledge and the right attitude of mind. The middle streams will come somewhere in between, but the approach is always made through the girls' interest in home making and cooking as a craft. They are taught to cook and to practise good kitchen hygiene, while learning the value of the foods they handle. Parallel with this goes some study of their needs and the practical work is reinforced with more or less reading, discussion and the study of charts or pictures suited to their powers. Such aids as the film and film strip are enlisted. The emphasis should always be, first, on the body's needs and how to supply them and, second, on how to make foods palatable and digestible without detracting unnecessarily from their value.

The extent and type of the work will vary with circumstances, which include the powers and interests of the teachers, not all of whom are yet either adequately informed or convinced of the subject's importance.

The best that can be done at present for most boys is to turn them out with some idea culled from their science of how to choose a properly balanced meal when occasion arises. 


\section{Grammar Schools}

The situation in the Grammar School is somewhat different. The pupils are more intelligent, but the curriculum is wider and less time is available. Not all pupils take housecraft and the ablest are seldom included. How much nutrition is done in science depends on the kind taken, and pupils, potential mothers and makers of cultured homes, may leave school with no knowledge at all of the subject.

Housecraft, when taken, is apt to be dropped after the 2 nd or 3 rd year, unless continued as an examination subject, when a modest but useful background is acquired. Often, however, the time allowance is scanty and the best brains are not included, so that something akin to cramming may occur. It is unfortunate if housecraft is taken as an alternative to science, for then not much more may be attempted than the assimilation of a few scientific rules.

Girls who take housecraft for General Certificate purposes seldom intend to follow the subject much further, so they are probably just adequately catered for, and those who propose to specialize usually drop it early and concentrate on science and English at school. These may acquire a useful background in biology and chemistry and will seek information from more academic sources. Their conception of food hygiene may be reinforced with a little bacteriology, and they may undertake some quantitative and comparative study of food values. Much depends on the timetable and on the literature and other facilities available, but the aim is to send them forward with a good scientific background on which to build further study.

Good sixth form courses dealing effectively with housecraft and its science are increasing, though housecraft courses are as yet most frequently of the homemaking type designed for girls whose education will shortly terminate. It is hoped, however, that the situation will improve as the examining bodies become interested and that in due course sound developments will take place to establish the subject on a level at least commensurate with that of other advanced sciences in the sixth form.

\section{SUMMARY}

The education of schoolchildren in nutrition may proceed throughout school life. Attempts are made at all stages to present by implication and by direct teaching such material as the pupil can understand and appreciate, the methods employed being appropriate to the pupils' powers and interests at any stage. How much can be done depends on the aptitude of the pupils and the facilities available, the aim being always to provide as much useful knowledge as the pupil can safely assimilate and is likely to require in order to maintain good health and, when appropriate, to prepare for further study at a higher level. It is not, however, considered advisable to embark upon a too highly academic approach with pupils of limited powers, for fear of confusing the issue. For them a few simple facts thoroughly taught, and emphasized by frequent practice in handling simple situations related to daily life, are found to offer the most beneficial approach. 